MEMORANDUM ON

\section{CLINICAL TOURS FOR} MEDICAL PRACTITIONERS.

\author{
By SIR HENRY M. W. GRAY \\ K.B.E., C.B., C.M.G., \\ Montreal, Canada.
}

THE function of such tours is prinlarily to provide adequate opportunity for individuals to study the professional work and the conditions under which it is carried out, and to come in personal contact with the professional workers of the country which is visited. In certain cases the secondary aims may be even more important, namely, to give time and facilities to observe the everyday life of the people inhabiting that country, to become acquainted with their customs, the "lay-out" of their cities, their systems of education, their industries, their architecture, their music, their art, their amusements and their politics (or the reason why such things should be so).

The attainment of these ideal objectives would foster understanding and sympathy between visitors and hosts to a degree otherwise unattainable during the short period available to the ordinary medical man.

Practitioners of medicine and surgery can be, and often are, amongst the most important influences in the community which they serve. Such clinical tours should be, therefore, of far-reaching value in international relationships. If reciprocity, by exchange of visits, is established, this value should be enhanced. Medical men, in virtue of their training, their powers of observation and deduction, the importance of their service, their tact and their instinct of diffusing knowledge, have in the past made wonderful missionaries. It is unnecessary to enlarge upon the possibilities of furthering international amity which spring to the mind.

Experience has shown that large parties are not really suitable for either social or professional purposes. They are unwieldy. Socially they monopolize the general accommodation and amusements provided on the voyage across the Atlantic, and in other ways may taint the regard in which the whole party is held. This tainted regard is apt to be extended to the profession, and indeed to the nation of which the company forms a part.

Large parties require very special arrangements to be made for them in whatever country or town they propose to visit. Except in the very largest centres, such as London, Paris or Berlin, they swamp the clinics, so that it may be possible for only the very pushful and inconsiderate few to reap maximum benefit. Other individuals, by nature less obtrusive, and incidentally usually more likeable, do not care to join in the push, and soon turn attention to other attractions. Dissatisfaction arises, and ideals are thwarted. Their hosts look forward with lessened interest, and maybe even with dread, to the repetition of similar. visits.

There is an increasing and, one might say, almost an insatiable desire on the part of keen medical men, in every country, to see what is being done elsewhere and to hear what leaders of the profession have to say on matters which interest them. Now can that desire be gratified in a way which will give satisfaction to those seekers after information and at the same time be least irksome, or rather most pleasant, to the workers who can provide it?

It is felt that a proper solution is indicated by the experience of a small party of medical men, from the United States and Canada, who visited various clinics in England last summer. Professional interests were catered for in Liverpool, Leeds, Manchester, Birmingham and London. Time was given for sight-seeing, \&c., in these towns. Trips 
were made to Chester, the Shakespeare Country, Oxford and Windsor. Relatives and certain non-medical friends accompanied the party but, of course, took no part in the professional work.

The tour was pronounced an unqualified success. The members of the party were charmed with the reception they had everywhere, both from institutional bodies and from individuals, with the professional work presented to them and with the arrangements made for their entertainment otherwise. The officials of the Fellowship of Medicine in London were indefatigable in their much appreciated attention to the party. The tour arranged in England lasted for only a fortnight. Most of the party made a short visit thereafter to the "Continent." A few retraced their steps to the clinics they had already visited. All came home with the desire to make a similar trip at no distant date. It was felt that, in every respect, the trip came nearer to fulfilling the objectives already indicated than any previous venture of the kind.

There can be no question about the desirability of organizing such tours. That they are of permanent professional value and provide great pleasure to the visitors are equally unquestionable facts. They are bound to be of international value in virtue of the reciprocal good feeling they engender.

As a result of the experience of last summer's tour, it can be said that very little organization is required. Certain established tourist agencies are willing to arrange transport and hotel accommodation and make arrangements for sight-seeing. Parties of not more than thirty professional men with their wives or older children are easily looked after. Thirty doctors visiting any large hospital need not interfere with the routine of that hospital. To see operations, to participate in ward rounds and discussion of cases, to have opportunity of seeing the general arrangements of the hospital and possibly to hear short addresses by prominent workers are what the great bulk of proz fessional visitors desire. While the succes\& of these visits is dependent on simple loca: arrangements, such as the drawing up of programme and appointment of someone t\$ receive and guide the party, it seems emi nently desirable that a professional inter national Board should be established fo controlling the tours. This Board mighe consist of a prominent physician and surgeon from, say, each of the following countries : the United States, France, Italy Germany, Holland, Great Britain and the Overseas Dominions. This Board would. tend to stimulate reciprocity. It could collaborate with the tourist agency. The Board need not dictate local arrangements but should receive and make recommenda tions which are likely to make for greater success.

Parties from North America visiting England may be taken as an example $\AA$ what could be done. Two such parties might be organized each month. On thes voyage over, daily meetings could be⿳亠丷厂 arranged for addresses or discussions This would allow the members of the parties to become acquainted. In England one party might spend two days each in, say, Liverpool, Birmingham, Manchester and? Newcastle, while the other party mighe spend two days each in Leeds, Sheffield Cardiff and Bristol. Both parties might?. then spend three days in London under theo auspices of the Fellowship of Medicine. IR three weeks were spent in England, the "non-professional." days could be filled upo according to the plans of the touring agency.

Such small parties could be made up onces a month for three or four months everyw year. In each provincial town, the Medica传 Faculty or Hospital Staffs might arrange programmes and appoint a suitable man to act as "guide" for each year. Such an experience would be of great value to a young man, from many angles. Visitors would desire that their hosts should not be put tọ 
any expense on their behalf. After the experience of a year, expenses which are incurred and which should be paid for by such visitors could be estimated and included in future charges, to be collected by the tourist agency.

\section{$\overline{\overline{2}}$ \\ THE FELLOWSHIP OF MEDICINE.}

REPORT OF THE HONORARY SECRETARIES FOR THE YEAR 1927.

THE Honorary Secretaries are happy to report that 1927 has been the most successful year the Association has enjoyed since its foundation in 1918-19 (it was in 1919 that the Fellowship of Medicine was amalgamated with the Post-Graduate Medical Association), and, for your interest, they relate its principal activities.

\section{CORRESPONDENCE.}

From January to December, 1927, some $\mathrm{I}, 590$ letters were dealt with by the Staff. These figures do not include letters written to various members of the Council, to hospital officials, \&c., but were the result of inquiries from post-graduates at home and abroad, and the total is divided as follows: London 576 , provincial 559 , and abroad $45^{\circ}$.

\section{Courses.}

The various courses organized by the Fellowship have been well patronized, as the following figures will show: The first table gives the number of individuals each year, from 1925 onwards, who have taken out tickets for courses :-

$\begin{array}{llll}\text { I } 923 & \ldots & \ldots & \text { I6I } \\ \text { I } 924 & \ldots & \ldots & 399 \\ \text { I925 } & \ldots & \ldots & 5 \text { I I } \\ \text { I } 926 & \ldots & \ldots & 535 \\ \text { I } 927 & \ldots & \ldots & 560\end{array}$

The second table shows the number of general tickets issued, admitting to the general practice of the affiliated hospitals. These tickets may be taken out for any period from one week to one year, and it is interesting to note that the tickets for one month remain the most popular :-

$\begin{array}{llll}1923 & \ldots & \ldots & 147 \\ 1924 & \ldots & \ldots & 226 \\ 1925 & \ldots & \ldots & 230 \\ 1926 & \ldots & \ldots & 254 \\ 1927 & \ldots & \ldots & 163\end{array}$

At first sight the figures for 1927 seem to indicate a big decrease on previous years, but it should be noted that they do not include seventy-three books of vouchers issued during 1927. These books of vouchers were instituted in 1925 , after the discussion on post-graduate education held in that year, when it was pointed out that the Fellowship of Medicine made no provision for practitioners unable to spare more than one or two half-days a week for post-graduate study. The books contain twelve or twenty-six tickets, are valid for six months from the date of issue, and entitle the practitioner to attend clinics on the same terms as the ordinary general ticket-holder -one ticket being given up at each attendance.

The Special Courses in 1927 have been, on the whole, satisfactorily attended, as the following figures demonstrate :-

$$
\begin{array}{rrrr}
1923 & \ldots & \ldots & 68 \\
1924 & \ldots & \ldots & 554 \\
1925 & \ldots & \ldots & 658 \\
\text { I926 } & \ldots & \ldots & 623 \\
\text { I927 } & \ldots & \ldots & 599
\end{array}
$$

The total number of tickets issued for all courses was $83 \mathrm{I}$, including the books of vouchers.

The following table shows the cosmopolitan character of the post-graduates attending the various courses:- 